Author version: Ocean Sci. J.: 44(2); 2009; 117-123

\title{
OXYGEN ISOTOPE RECORDS OF GLOBIGERINA BULLOIDES ACROSS A NORTH-SOUTH TRANSECT IN THE SOUTH-WESTERN INDIAN OCEAN
}

\author{
N. Khare $^{1^{*}}$, S. K. Chaturvedi ${ }^{2}$ and R. Saraswat ${ }^{3}$ \\ 1. Ministry of Earth Sciences, Block \# 12, CGO Complex, Lodhi Road, New Delhi - 110003 \\ (India) (Email: nkhare45@gmail.com) \\ 2. Department of Disaster Management, SASTRA University, Thanjavur - 613 402, (India), (E- \\ mail: chaturvedi@carism.sastra.edu) \\ 3. National Institute of Oceanography, Dona Paula, Goa - 403004 (India) \\ *Corresponding Author: N. Khare, Email: nkhare45@gmail.com
}

\begin{abstract}
Oxygen isotopic analysis of planktic foraminifera (Globigerina bulloides) from a total of 23 surface sediment samples collected along a north-south transect $\left(9.69^{\circ} \mathrm{N}\right.$ to $\left.55.01^{\circ} \mathrm{S}\right)$ in the southwestern Indian Ocean during the Indian Pilot Expedition to Southern Ocean (PESO), was carried out to assess the relationship between oxygen isotopic composition and ambient seawater temperature and salinity. An increasing trend in the $\delta^{18} \mathrm{O}$ value is noticed towards higher latitude. Apparently such an increase in $\delta^{18} \mathrm{O}$ values is inversely related to the seawater temperature changes along the transect. However, slight mismatch is observed at a few stations, which is attributed to significant seawater salinity changes. The preliminary results of the present study, if extended to the subsurface sediments coupled with other parameters, may contribute to the reconstruction of the paleohydrography of the region, especially the position of various seawater fronts during the geologic past, albeit with areal limitation.
\end{abstract}

Key Words: Foraminifera, Globigerina bulloides, Oxygen isotopes, Southwestern Indian Ocean, Fronts, Water masses. 


\section{Introduction}

Numerous studies have been carried out in the northern Indian Ocean and also in the Indian Ocean region around Australia, to understand the relationship between various characteristics of foraminifera (unicellular, preferentially marine microorganisms, which are among one of the most extensively used proxies), and seawater physico-chemical properties (Hutson, 1977; Corliss, 1979; Nigam \& Khare, 1995; Rathburn \& Dedeckker, 1997; Chowdhury et al., 2003; Naidu \& Niitsuma, 2004; Ding et al., 2006). However, limited attention has been paid to the southwestern Indian Ocean, although Hutson (1977) studied the effect of water masses and dissolution on the foraminiferal distribution in the western Indian Ocean.

Similarly, Hutson (1978) developed a transfer function for seawater temperature estimation from the faunal distribution in plankton and core top samples, and suggested that the transfer function should be calibrated by using core top samples rather than the plankton samples. Corliss (1983) studied the foraminiferal distribution in the core top sediments and observed a broad correlation between faunal distribution and seawater characteristics but definite factors controlling the faunal distribution could not be reported.

After the pioneering work of Emiliani (1955), continuous efforts have been made to refine the paleotemperature equations (Bemis et al., 1998, 2002). It is based on the calibration from plankton/core top foraminiferal oxygen isotopic ratio and seawater temperature, gathered from different parts of the world oceans including the Indian Ocean (Duplessy et al., 1981; Mulitza et al., 2003) Graham et al. (1981) studied the relationship between stable isotopic composition of benthic foraminifera and seawater temperature using core top sediments from deep sea throughout the world oceans including southwestern Indian Ocean. But limited attempt has been made to understand such relationship from the southwestern Indian Ocean. In order to fulfill this gap and understand the past climate changes in the southwestern Indian Ocean, a number of surface and sub surface sediment samples were collected during the Pilot Expedition to Southern Ocean (PESO).

The surface sediment samples were used to understand the relationship between the oxygen isotopic composition of the planktic foraminiferal species G. bulloides and the ambient seawater temperature. The G. bulloides was chosen for the present study as sufficient number of specimens of $G$. bulloides were available in the samples and also because its oxygen isotopic 
composition has previously been used to estimate the past seawater temperature (Gao et al., 1985; Bemis et al., 2002).

G. bulloides is a sub Antarctic and transitional species found mainly within upper $60 \mathrm{~m}$ of the water column, in and above the seasonal thermocline (Hemleben et al., 1989) where sea surface temperature (SST) ranges between $10^{\circ}$ and $18^{\circ} \mathrm{C}$, surface salinity is lower than $35.5 \%$ and water is rich in dissolved phosphate and silicate (Bé \& Hutson, 1977; Schiebel et al., 1997). However, its depth distribution can be modified by the availability of its diet and therefore, by hydrographical conditions. It has widely been used as upwelling indicator (Gupta et al., 2003; Naidu, 2004, Peeters et al., 2002; Prell \& Curry, 1981). From the Indian Ocean, abundant presence of $G$. bulloides has been reported between $40^{\circ} \mathrm{S}$ and $55^{\circ} \mathrm{S}$ latitudes, over a seawater temperature range of $0-27^{\circ} \mathrm{C}$ (Bé \& Tolderlund, 1971). Majority of the samples used for the present study, except four samples (SK 199/C01, 02, 05 and 06), lie within this temperature range. However, only $\sim$ one-third of the samples lie within the optimal latitudinal zone.

\section{Oceanography of the study area}

The studied area is an integral part of both Indian and Southern Oceans. Indian Ocean exhibits a unique oceanographic characteristic. Unlike the Pacific and Atlantic Ocean which communicate to both North and South Poles, the Indian Ocean has its northern boundary closed with land mass (Fig. 1).

The northern Indian Ocean experiences seasonally reversing seawater circulation (Wyrtki, 1973) with a characteristic change in the equatorial currents. The westward flowing North Equatorial Current (NEC) is prominent in January and March when the Northeast monsoon is fully established. It runs as a narrow current from Malacca Strait to Southern Sri Lanka, where it bends southward between $2^{\circ} \mathrm{S}$ and $5^{\circ} \mathrm{N}$ in the region between $60^{\circ} \mathrm{E}$ and $75^{\circ} \mathrm{E}$. The South Equatorial Current (SEC) occupies the region south of $8^{\circ} \mathrm{S}$. Between the two westward flows, the Equatorial Counter Current (ECC) is occupied.

The circulation in the Southern Indian Ocean is characterized by a subtropical Anticyclone gyre (Wyrtki, 1971). The poleward flowing Agulhas Current lies on its west, the eastward flowing Antarctic Circumpolar Current (ACC) on its south and equatorward flowing Western Australian Current on its east. The Subtropical Front (STF) is located at approximately $40^{\circ} \mathrm{S}$ in the central south Indian Ocean (Stramma, 1992). It is significant to note that between the 
fronts lie zones of relatively uniform water mass properties. From north to south, a series of fronts and zones are developed in the Southern Ocean: the Subtropical Front (STF), Subantarctic Zone (SAZ), Subantarctic Front (SAF), Polar Frontal Zone (PFZ), Polar Front (PF) and Antarctic Zone (AZ) (Whiteworth, 1980).

\section{Materials and Methods}

A total of twenty three surface sediment samples (comprising Peterson grab, piston core top, gravity core top and spade core top samples) collected during $199 \mathrm{C}$ and $200^{\text {th }}$ cruises of ORV Sagar Kanya are utilized in the present study. The $200^{\text {th }}$ cruise from Mauritius to further south is christened as the Pilot Expedition to Southern Ocean (PESO) covering a transect between latitude $9.69^{\circ} \mathrm{N}$ and $55.01^{\circ} \mathrm{S}$ and longitude $80^{\circ} \mathrm{E}$ and $40^{\circ} \mathrm{E}$ in the southwestern Indian Ocean and part of the Indian sector of the Southern Ocean (Figure 1; Table 1) during the late austral summer and early fall (January to March 2004).

The calcium carbonate compensation depth (CCD) and lysocline in and around study area lie below 4,400-4,700 meter water depth (Banakar et al., 1998). All sampling depths are much above the CCD and lysocline and thus, possibility of any dissolution effect on the planktic foraminifera may be ruled out. Immediately after recovery all the sediment samples (top $1 \mathrm{~cm}$ of the sediment core/grab) were stained with Rose Bengal and preserved in $10 \%$ formalin to differentiate the living and dead specimens of benthic foraminifera. Though, all possible efforts were made to collect the surface sediments so as to sample the Recent sediments, we believe that at few locations, slightly older sediments might have been collected. Without exact dating of these sediment samples, the presence of living benthic foraminiferal specimen at various stations may be considered as indicator of the Recent ambient conditions. In order to avoid the ambiguity, foraminiferal characteristics were compared with the annually averaged surface hydrographic properties (Levitus, 1994), instead of snap-shot measurements during the cruise.

In order to determine the oxygen isotope ratio of the foraminifers, sediment samples were processed as per standard procedures. An appropriate amount of sediment from each sample was dried overnight at $45^{\circ} \mathrm{C}$. Dried sediment samples were soaked in distilled water and subsequently treated with sodium hexametaphosphate in order to dissociate clay lumps. The treated sediments were sieved in $63 \mu \mathrm{m}$ sieve. The $>63 \mu \mathrm{m}$ fraction was dried and transferred to plastic vials. The $>63 \mu \mathrm{m}$ fraction was dry sieved to get $>150 \mu \mathrm{m}$ fraction. From the $>150 \mu \mathrm{m}$ fraction, an aliquot 
was taken by coning and quartering, to pick 10-12 specimens G. bulloides for stable isotopic (oxygen) analyses. Globigerina bulloides species was selected for the isotopic analysis because of its ubiquitous presence in all the samples.

The isotopic composition of G. bulloides specimens was determined at the Alfred Wegener Institute for Polar and Marine Research, Germany, with a Finnigan MAT 251 isotope ratio gas mass spectrometer coupled to an automatic carbonate preparation device (Kiel I) and calibrated via NBS 19 to the PDB scale. The values are given in $\delta$-notation versus VPDB (Vienna Pee Dee Belemnite). Precision of oxygen measurements based on repeated analyses of a laboratory standard over a year-period was better than $0.09 \%$ for oxygen. The average annual sea surface temperature and salinity at $75 \mathrm{~m}$ water depth, across the transect of the study area was obtained from Levitus dataset (Levitus et al., 1994) and is listed in Table 1. The correlation coefficient is calculated and plotted using Grapher (version 4.0) software. In order to increase the reliability of the findings, the results were compared with the sea surface temperature and $\delta^{18} \mathrm{O}$ of Globigerinoides ruber, in a nearby north-south transect of Duplessy et al. (1981).

\section{Results}

The minimum value of $\delta^{18} \mathrm{O}$ G. bulloides is $-2.25 \%$ recorded at station SK $199 \mathrm{C} / 1$, whereas it reaches the maximum (3.13\%) at station SK 200/33 (Figure 2 a) (Table 1). The minimum seawater temperature recorded in this transect at around $75 \mathrm{~m}$ water depth is $1.38^{\circ} \mathrm{C}$ (at station SK 200/33) whereas maximum temperature $\left(28.50^{\circ} \mathrm{C}\right)$ was recorded at station SK199C/01 (Figure 2a; Table 1). G. bulloides in the open ocean, outside the upwelling zones, occurs at around the deep chlorophyll maximum, which is located below the surface mixed layer. It is typically associated with temperate to sub-polar water masses but is also present in lower latitudes upwelling regions (Naidu and Malmgren, 1996). G. bulloides is comparatively deep dwelling species, probably inhabiting the water above the thermocline. The thermocline in the studied area has been reported to vary within the range of 75-150 m (AnilKumar and others, 2005) and therefore, in the present study we have considered the average annual sea surface temperature at $75 \mathrm{~m}$ water depth.

The scatter plot between $\delta^{18} \mathrm{O}$ G. bulloides and seawater temperature (Figure 2b) clearly exhibits a reasonably good inverse relationship $\left(\mathrm{R}^{2}=0.88\right)$. It is evident that both parameters are apparently showing reverse trends from lower to higher latitude. In order to find out, if similar 
relationship is also observed between the oxygen isotopic ratio of surface dwelling planktic foraminiferal species Globigerinoides ruber and the seawater temperature, the $\delta^{18} \mathrm{O} G$. ruber was plotted against the seawater temperature (Figure 3a) as given by Duplessy et al. (1981) in a north-south transect in the nearby region. The scatter plot of $\delta^{18} \mathrm{O}$ G. ruber against the seawater temperature also shows significant inverse relationship $\left(\mathrm{R}^{2}=0.96\right)$ (Fig. 3b). The plot confirms the relationship as observed between G. bulloides and seawater temperature.

\section{Discussion}

${ }^{18} \mathrm{O} /{ }^{16} \mathrm{O}$ ratio in foraminiferal test is mainly a function of the ${ }^{18} \mathrm{O} /{ }^{16} \mathrm{O}$ ratio in seawater and the calcification temperature (McCrea, 1950; Epstein et al., 1953). The oxygen isotopic analysis of calcareous microfossils has been widely used to quantitatively estimate paleotemperature, salinity, upwelling, etc. (Shackleton \& Kennett, 1975; Savin et al., 1981; Miller et al., 1987; Hoefs, 1997, Naidu, 2004). Based on the studies in the northern Indian Ocean and other world oceans, it has been reported that the stable isotopic composition of G. bulloides reflects the physico-chemical conditions (such as temperature, salinity, eutrophication, depth setting, seasonality, etc.) of the seawater in which it calcifies its test (Naidu \& Niitsuma, 2004; Gao et al., 1985; Bemis et al., 2002). Here, we have considered the effect of temperature on $\delta^{18} \mathrm{O}$ of $G$. bulloides. Figure 2a clearly shows that $\delta^{18} \mathrm{O}$ of $G$. bulloides increases towards the southern high latitudes. Along the same transect, sea surface temperature shows a decreasing trend (Figure 2a). Such an increase in the $\delta^{18} \mathrm{O}$ towards higher latitude could be better explained in the light of temperature changes linked with the latitudinal differences. A vast difference in the temperature values of ambient near surface seawater (ranging from $2.21^{\circ} \mathrm{C}$ to $29.15^{\circ} \mathrm{C}$ ) is recorded along the selected transect with an overall decreasing trend (Figure 2a). The slight incongruency at few stations probably reflects either the calcification out of optimal conditions, or the effect of seawater salinity. Though the results show that temperature appears to be one of the factors controlling $\delta^{18} \mathrm{O}$ of calcareous shells of planktic foraminifera along the study area, yet the secondary control of salinity can not be ignored. However, the exact causal explanation to such mis-match is beyond the scope of the present study.

Our findings are important for the application of oxygen isotopic ratio of G. bulloides for paleoceanographic history of southwestern Indian Ocean and the region further south. Therefore, temperature changes linked to the water mass structure and cold climate conditions towards the 
Antarctic region are the apparent cause for the variations with an increasing $\delta^{18} \mathrm{O}$ trend from lower to higher latitude

\section{Conclusions and Implications}

It is evident from the previous studies that a sedimentary boundary separates the carbonate rich sediments to the north from the opal rich sediments to the south and the position of the Polar Front is associated today with higher surface productivity (Lutjeharms et al., 1985; Matsumoto et al., 2001). Earlier studies have also suggested that this boundary has been shifted northward by $7^{\circ}$ during the Last Glacial Maxima (LGM) compared to the Holocene that has been used as a supporting evidence for a northward migration of the Polar Front (Hays et al., 1976). Seawater temperature is one of the important hydrographic properties to define the Polar Front and other physical oceanographic features (Matsumoto et al., 2001).

Detection of the signature of the frontal movement in the southwestern Indian Ocean and further south, utilizing foraminiferal proxies will definitely be helpful in understanding the fact whether the basic Southern Ocean hydrography, including stratification and the mean position of the Antarctic Circum Polar Current, Frontal System remain unchanged or got changed in this region as compared to the other sectors (like Pacific, Atlantic etc.) of the Southern Ocean. However, south of Polar Front, it is very difficult to obtain the calcareous fossils and therefore, the proposed technique poses certain areal limitation for its application in high latitude regions Furthermore, the role of salinity in controlling the oxygen isotope concentration in foraminiferal test across the selected transects may not be ruled out. Such aspects are being studied in detail and results will be published separately

\section{Acknowledgments}

The authors are grateful to Dr. Shailesh Nayak, Secretary, Ministry of Earth Sciences for his kind support and encouragement to publish the results. Prof. A. Mackensen and laboratory staff at Alfred Wegener Institute for Polar and Marine Research, Bremerhaven, Germany, are thankfully acknowledged for providing facilities for oxygen isotope analyses. Master, officers and crew of ORV Sagar Kanya are acknowledged for providing logistics support during the collection of the samples. R.S. is thankful to the Director, National Institute of Oceanography, Goa for the permission to publish the findings and UGC-DAAD for awarding the fellowship. We 
are grateful to two anonymous referees whose constructive comments helped us to improve the quality of the manuscript. 


\section{References}

Anilkumar, N., Dash, M.K., Luis, A.J., Ramesh Babu, V., Somayajulu, Y.K., Sudhakar, M. and Pandey, P.C., 2005. Oceanic front along $45^{\circ}$ east across Antarctic Circumpolar current during Austral summer 2004. Curr. Sci. 88, 1669-1673.

Banakar, V., K. Parthiban, G. Pattan and J.N. Jauhari. 1998. Chemistry of surface sediment along a north south transect across the equator in the central Indian basin: an assessment of biogenic and detrital influences on elemental burial of the sea floor. Chem. Geol., 147, 217232.

Bé, A.W.H. and W.H. Hutson. 1977. Ecology of planktonic foraminifera and biogeographic patterns of life and fossil assemblages in the Indian Ocean. Micropaleont., 23, 369-414.

Bé, A.W.H. and Tolderlund, D.S. 1971. Distribution and ecology of living planktonic foraminifera in surface waters of the Atlantic and Indian Oceans. In Funnel, B.M., Riedel, W.R. (eds), The Micropaleontology of Oceans, pp. 105-149.

Bemis, B.E., Spero, H.J., Bijma, J. and D.W. Lea. 1998. Reevaluation of the oxygen isotopic composition of planktonic foraminifera: experimental results and revised paleotemperatue equations. Paleoceanography, 13, 150-160.

Bemis, B.E., H.J. Spero and R.C. Thunell. 2002. Using species-specific paleotemperature equations with foraminifera: a case study in the Southern California Bight. Mar. Micropaleont., 46, 405-430.

Chowdhury, K.R. Haque, M.M.N. Nasreen and M.R. Hasan. 2003. Distribution of planktonic foraminifera in the northern Bay of Bengal. Sediment. Geol., 155, 393-405.

Corliss, B.H. 1979. Recent deep-sea benthonic foraminiferal distributions in the southeast Indian Ocean: inferred bottom-water routes and ecological implications. Mar. Geol., 31, 115-138.

Corliss, B.H. 1983. Distribution of Holocene deep-sea benthonic foraminifera in the southwest Indian Ocean. Deep Sea Res., 30, 95-117.

Ding, X., Bassinot, F., Guichard, F., Li, Q.Y., Fang, N.Q., Labeyrie, L., Xin, R.C., Adisaputra, M.K., Hardjawidjaksana, K., 2006. Distribution and ecology of planktonic foraminifera from the seas around the Indonesian Archipelago. Mar. Micropaleontol., 58:114-134.

Duplessy, J.C., A.W.H. Bé and P.L. Blanc. 1981. Oxygen and carbon isotopic composition and biogeographic distribution of planktonic foraminifera in the Indian Ocean. Palaeogeogr. Palaeoclimatol. Palaeoecol., 33, 9-46. 
Emiliani, C. 1955. Pleistocene temperatures. J. Geol., 63, 538-576.

Epstein, S., R. Buchsbaum, H.A. Lowenstam and H.C.Urey. 1953. Revised carbonate-water isotopic temperature scale. Goel. Soc. Am. Bull., 64, 1315-1325.

Gao, L., K.O. Emery and L.D. Keigwin. 1985. Late Quaternary stable isotope paleoceanography of southern California. Deep Sea Res., 32, 1469-1484.

Graham, D.W., B.H. Corliss, M.L. Bender and L.D. Keigwin. 1981. Carbon and oxygen isotopic disequilibria of recent deep-sea benthic foraminifera. Mar. Micropaleontol., 6, 483-497.

Gupta, A.K., D.M. Anderson and J.T. Overpek. 2003. Abrupt changes in the Asian southwest monsoon during the Holocene and their links to the North Atlantic Ocean. Nature, 421, 354-357.

Hays, J.D., J.A. Lozano, N.J. Shackleton and G. Irving. 1976. Reconstruction of the Atlantic and western Indian Ocean sectors of the 18,000 BP. Antarctic Ocean. p. 337-372. In: Investigation of Late Quaternary Paleoceanography and Paleoclimatology. ed. by R.M. CLINE and J.D. HAYS. Geological Society of America.

Hemleben, CH., M. Spindler and O.R. Anderson. 1989. Modern Planktonic Foraminifera. Springer-Verlag New York Inc., 363 p.

Hoefs, J. 1997. Stable isotope Geochemistry. Springer, Berlin, 201 p.

Hutson, W.H. 1977. Variations in planktonic foraminiferal assemblages along north-south transects in the Indian Ocean. Mar. Micropaleontol., 2, 47-66.

Hutson, W.H. 1978. Application of transfer functions to Indian Ocean planktonic foraminifera. Quat. Res., 9, 87-112.

Levitus, S., Burgett, R., Boyer, T. 1994. World Ocean Atlas 1994, (NOAA Atlas NESDIS 3, U.S. Department of Commerce, Washington, D.C).

Lutjeharms, J.R.E., N.M. Walters and B.R. Allanson. 1985. Oceanic frontal systems and biologicalenhancement. p.11-21. In: Antarctic Nutrient Cycles and Food Webs. ed. by W.R. Siegfried et al., Springer-Verlag, NewYork.

Matsumoto, K., J. Lynch-Stieglitz and R.F. Anderson. 2001. Similar glacial and Holocene Southern Ocean hydrography. Paleoceanography, 16, 1-10.

McCrea, J.M. 1950. On the isotopic chemistry of carbonates and a paleotemperature scale. J. Chem. Phys., 18, 849-857. 
Miller, K.G., R.G. Fairbanks and G.S. Mountain. 1987. Tertiary oxygen isotope synthesis, sea level history, and continental margin erosion. Paleoceanography, 2, 1-19.

Mulitza, S., D. Boltovskoy, B. Donner, H. Meggers, A. Paul and G. Wefer. 2003. Temperature: $\delta^{18} \mathrm{O}$ relationships of planktonic foraminifera collected from surface waters. Palaeogeogra. Palaeoclimatol. Palaeoecol., 202, 143-152.

Naidu, P.D. 2004. Isotopic evidences of past upwelling intensity in the Arabian Sea. Glo. Pla. Cha., 40, 285-293.

Naidu, P.D. and N. Niitsuma. 2004. Atypical d13C signature in Globigerina bulloides at the ODP site 723A (Arabian Sea): implications of environmental changes caused by upwelling. Mar. Micropaleontol., 53, 1-10.

Naidu, P.D. and Malmgren, B.J., 1996, A high resolution record of late Quaternary upwelling along the Oman Margin, Arabian Sea based on planktonic foraminifera: Paleoceanography, 11, 129-140.

Nigam, R. and N. Khare. 1995. Significance of correspondence between river discharge and proloculus size of benthic foraminifera in paleomonsoonal studies. Geo-Mar. Lett., 15, 4550.

Peeters, F.J.C., G.J.A. Brummer and G. GanesseN. 2002. The effect of upwelling on the distribution and stable isotope composition of Globigerina bulloides and Globigeroinoides rubber (planktonic foraminifera) in modern surface waters of the NW Arabian Sea. Glo. Pla. Cha., 34, 269-291.

Prell, W.L. and Curry, W.B. 1981. Faunal and isotopic indices of monsoonal upwelling: Western Arabian Sea. Oceanol. Acta., 4, 91-98.

Rathburn, A. E. and Deckker, P.D. 1997. Magnesium and strontium compositions of Recent benthic foraminifera from the Coral Sea, Australia and Prydz Bay, Antarctica. Mar. Micropaleontol., 32, 231-248.

Savin, S.M., R.G. Douglas, G. Keller, J.S. Killingely, L. Shaugnessy, M.A Sommer, E. Vincent and F. Woodruff. 1981. Mioence benthic foraminiferal isotope records : a synthesis. Mar. Micropaleontol. 6, 423-450.

Schiebel, R., J. Bijma and C. Hemleben. 1997. Population dynamics of the planktonic foraminifer Globigerina bulloides from the eastern North Atlantic. Deep Sea Res. I, 44, 1701-1713. 
Shackleton, N.J. and J.P. Kennett 1975. Paleotemperature history of the Cenozoic and the initiation of Antarctic glaciation: oxygen and carbon isotope analyses of DSDP site 277,279 and 281, 29,743-745. In: Initial Reports of the Deep Sea Drilling Project, Leg 29, ed. by J.P., Kennett and R.E. Houtz etal., U. S. Government Printing Office, Washington, D. C.

Stramma, L. 1992. The south Indian Ocean current. J. Phys. Oceanogr., 22, 325-347.

Whiteworth, T. 1980. Zonation and geostrophic flow of the Antarctic Circumpolar Current at Drake Passage. Deep Sea Res., 27, 497-507.

Wyrtki, K. 1971. Oceanographic Atlas of the International Indian Ocean Expedition. National Science Foundation, Washington D.C., 531p.

Wyrtki, K. 1973. An equatorial jet in the Indian Ocean. Science 181, 262-264. 


\section{List of Table}

Table 1: Showing details of sampling stations.

\section{List of Figures}

Figure 1: Map showing the locations of grab and Piston corer samples.

Figure 2a: Latitudinal changes of $\delta^{18} \mathrm{O}$ in Globigerina bulloides and seawater temperature at a water depth of $75 \mathrm{~m}$.

Figure 2b: Relationship between seawater temperature and $\delta{ }^{18} \mathrm{O}$ in Globigerina bulloides.

Figure 3a: Latitudinal changes of $\delta{ }^{18} \mathrm{O}$ in Globigerinodes ruber and seawater temperature (Modified after Duplessy et al., 1981).

Figure 3b: Relationship between seawater temperature and $\delta{ }^{18} \mathrm{O}$ in Globigerinoides ruber (Modified after Duplessy et al., 1981). 
Table 1

\begin{tabular}{|c|c|c|c|c|c|c|c|c|}
\hline \multirow{2}{*}{$\begin{array}{l}\text { Sr. } \\
\text { No. }\end{array}$} & \multirow{2}{*}{$\begin{array}{c}\text { Sample } \\
\text { No. }\end{array}$} & \multicolumn{2}{|c|}{ Location } & \multirow{2}{*}{$\begin{array}{l}\text { Water } \\
\text { depth } \\
(\mathrm{m})\end{array}$} & \multirow{2}{*}{$\begin{array}{l}\text { Sampling } \\
\text { method }\end{array}$} & \multirow{2}{*}{$\begin{array}{l}\delta^{18} \mathrm{O} \\
(\% 0)\end{array}$} & \multirow{2}{*}{$\begin{array}{c}\text { Temperature } \\
\left({ }^{\circ} \mathrm{C}\right) \\
(75 \mathrm{~m} \text { depth })\end{array}$} & \multirow{2}{*}{$\begin{array}{c}\text { Salinity } \\
\text { (75 m depth) }\end{array}$} \\
\hline & & Latitude & Longitude & & & & & \\
\hline 1. & SK199C/01 & $09^{\circ} 41.25^{\prime} \mathrm{N}$ & $75^{\circ} 45.15^{\prime} \mathrm{E}$ & 87 & Peterson Grab & -2.25 & 28.50 & \\
\hline 2. & SK199C/02 & $09^{\circ} 38.20^{\prime} \mathrm{N}$ & $75^{\circ} 36.19^{\prime} \mathrm{E}$ & 319 & Peterson Grab & -1.50 & 28.50 & \\
\hline 3. & SK199C/05 & $08^{\circ} 59.50^{\prime} \mathrm{N}$ & $74^{\circ} 49.31^{\prime} \mathrm{E}$ & 2738 & Peterson Grab & -2.05 & 28.22 & \\
\hline 4. & SK199C/06 & $08^{\circ} 08.00^{\prime} \mathrm{N}$ & $73^{\circ} 33.86^{\prime} \mathrm{E}$ & 2250 & Spade Corer & -0.91 & 25.78 & 35.44 \\
\hline 5. & $\mathrm{~K} 199 \mathrm{C} / 10$ & $01^{\circ} 55.38^{\prime} \mathrm{S}$ & $67^{\circ} 52.85^{\prime} \mathrm{E}$ & 2597 & Spade Corer & -1.09 & 24.58 & 35.32 \\
\hline 6. & SK199C/12 & $04^{\circ} 41.18^{\prime} \mathrm{S}$ & $67^{\circ} 05.75^{\prime} \mathrm{E}$ & 3320 & Spade Corer & -0.75 & 22.13 & 35.21 \\
\hline 7. & SK199C/13 & $07^{\circ} 21.89^{\prime} \mathrm{S}$ & $67^{\circ} 10.37^{\prime} \mathrm{E}$ & 3305 & Spade Corer & -1.11 & 20.67 & 35.06 \\
\hline 8. & SK199C/14 & $09^{\circ} 10.74^{\prime} \mathrm{S}$ & $65^{\circ} 57.33^{\prime} \mathrm{E}$ & 3373 & Spade Corer & -1.53 & 21.49 & 34.94 \\
\hline 9. & SK199C/15 & $11^{\circ} 25.46^{\prime} \mathrm{S}$ & $67^{\circ} 24.16^{\prime} \mathrm{E}$ & 3513 & Gravity Corer & -0.99 & 23.47 & 34.84 \\
\hline 10. & $\mathrm{~K} 199 \mathrm{C} / 16$ & $12^{\circ} 35.56^{\prime} \mathrm{S}$ & $67^{\circ} 08.59^{\prime} \mathrm{E}$ & 3722 & Gravity Corer & -1.09 & 24.05 & 34.82 \\
\hline 11. & K199C/17 & $15^{\circ} 16.71^{\prime} \mathrm{S}$ & $66^{\circ} 00.77^{\prime} \mathrm{E}$ & 3368 & Piston Corer & -1.35 & .28 & 34 \\
\hline 12. & $199 \mathrm{C} / 19$ & $16^{\circ} 16.06^{\prime} \mathrm{S}$ & $63^{\circ} 27.86^{\prime} \mathrm{E}$ & 4003 & Piston Corer & -0.03 & 24.23 & 34.87 \\
\hline 13. & SK200/05 & $28^{\circ} 19.29^{\prime} \mathrm{S}$ & $48^{\circ} 43.56^{\prime} \mathrm{E}$ & 2295 & Piston Corer & -0.63 & 20.75 & 35.44 \\
\hline 14. & SK200/09 & $30^{\circ} 54.85^{\prime} \mathrm{S}$ & $44^{\circ} 51.37^{\prime} \mathrm{E}$ & 2227 & Gravity Corer & -0.04 & 19.30 & 35.54 \\
\hline 15. & SK200/14 & $36^{\circ} 07.30^{\prime} \mathrm{S}$ & $44^{\circ} 53.54^{\prime} \mathrm{E}$ & 2805 & Piston Corer & 0.88 & 17.28 & 35.52 \\
\hline 16. & SK200/15 & $37^{\circ} 00.00^{\prime} \mathrm{S}$ & $44^{\circ} 59.00^{\prime} \mathrm{E}$ & 2984 & Peterson Grab & 0.45 & 17.08 & 35.48 \\
\hline 17. & SK200/17 & $39^{\circ} 01.71^{\prime} \mathrm{S}$ & $44^{\circ} 58.17^{\prime} \mathrm{E}$ & 4022 & Piston Corer & 1.13 & 15.97 & 35.24 \\
\hline 18. & SK200/19 & $40^{\circ} 58.88^{\prime} \mathrm{S}$ & $45^{\circ} 03.53^{\prime} \mathrm{E}$ & 2532 & Piston Corer & 2.82 & 13.03 & 34.77 \\
\hline 19. & SK200/21 & $43^{\circ} 09.00^{\prime} \mathrm{S}$ & $44^{\circ} 59.00^{\prime} \mathrm{E}$ & 3210 & Peterson Grab & 1.71 & 9.33 & 34.21 \\
\hline 20. & SK200/22A & $43^{\circ} 41.47^{\prime} \mathrm{S}$ & $45^{\circ} 04.22^{\prime} \mathrm{E}$ & 2723 & Piston Corer & 1.96 & 8.58 & 34.11 \\
\hline 21. & SK200/23 & $44^{\circ} 59.82^{\prime} \mathrm{S}$ & $45^{\circ} 00.83^{\prime} \mathrm{E}$ & 1423 & Piston Corer & 2.49 & 6.97 & 33.95 \\
\hline 22. & SK200/27 & $49^{\circ} 00.34^{\prime} \mathrm{S}$ & $45^{\circ} 13.11^{\prime} \mathrm{E}$ & 4377 & Gravity Corer & 2.94 & 3.96 & 33.88 \\
\hline 23. & SK200/33 & $55^{\circ} 00.39^{\prime} \mathrm{S}$ & $45^{\circ} 00.63^{\prime} \mathrm{E}$ & 4185 & Piston Corer & 3.13 & 1.38 & 33.98 \\
\hline
\end{tabular}




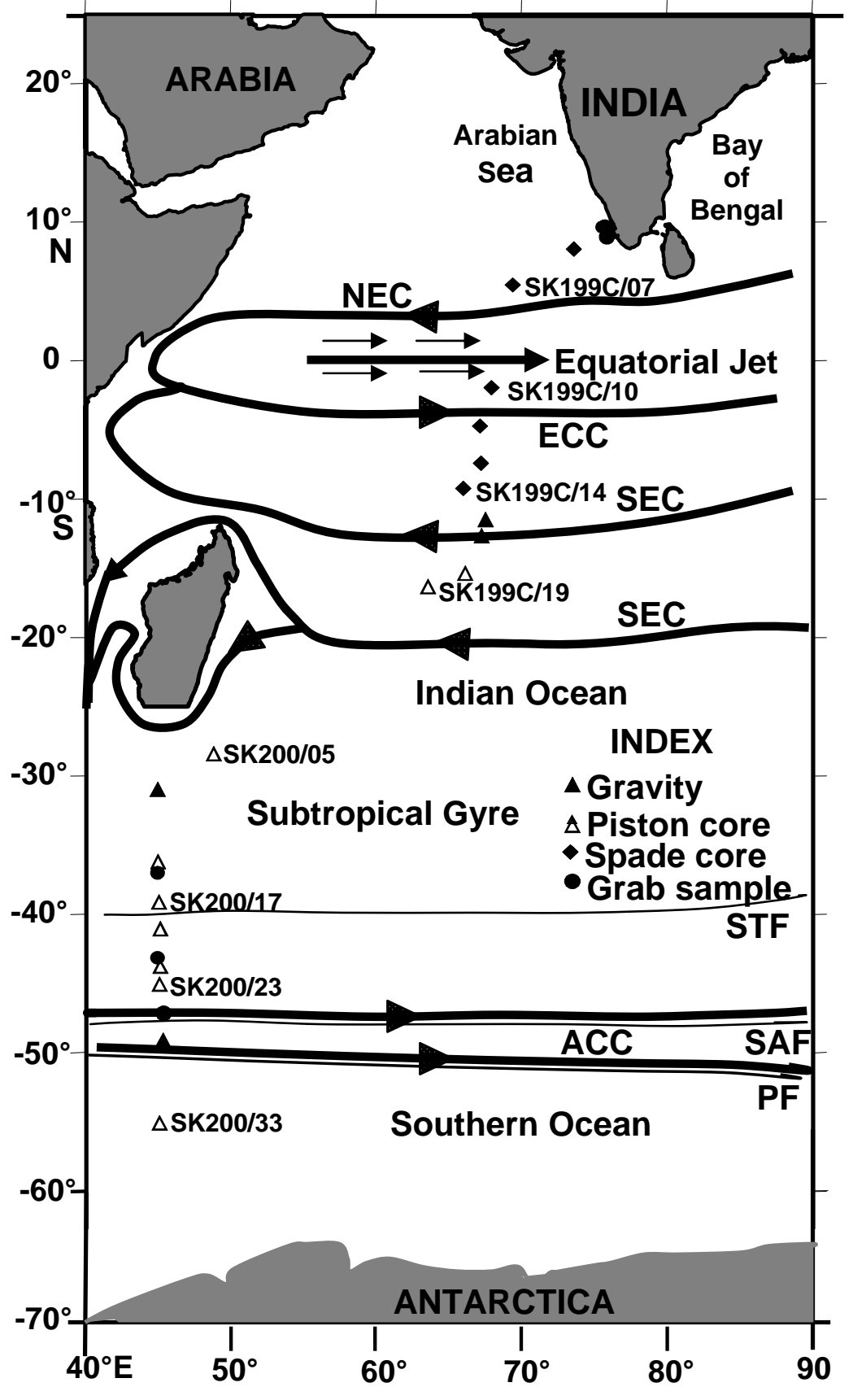

Figure: 1 

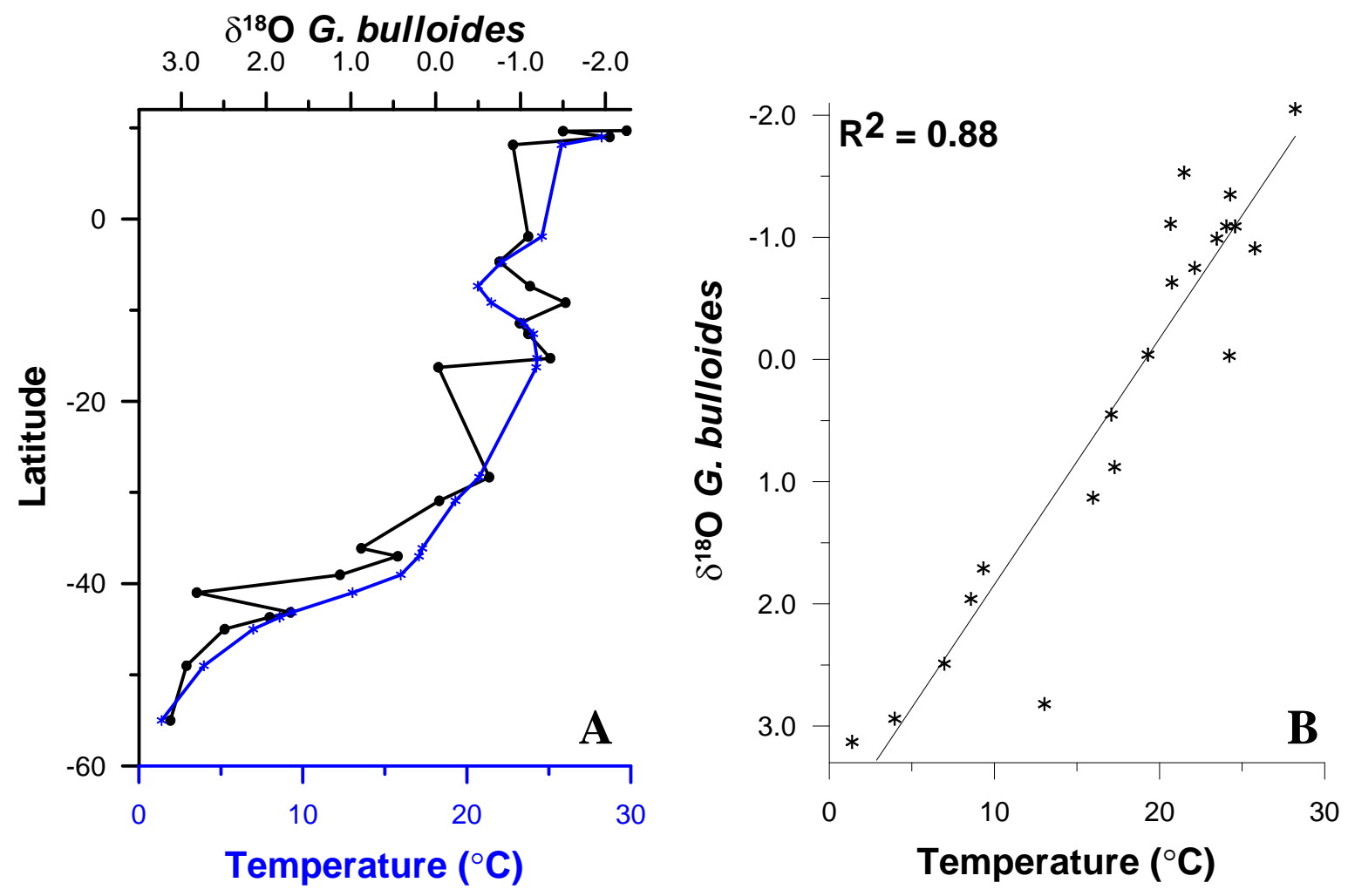

Figure: 2
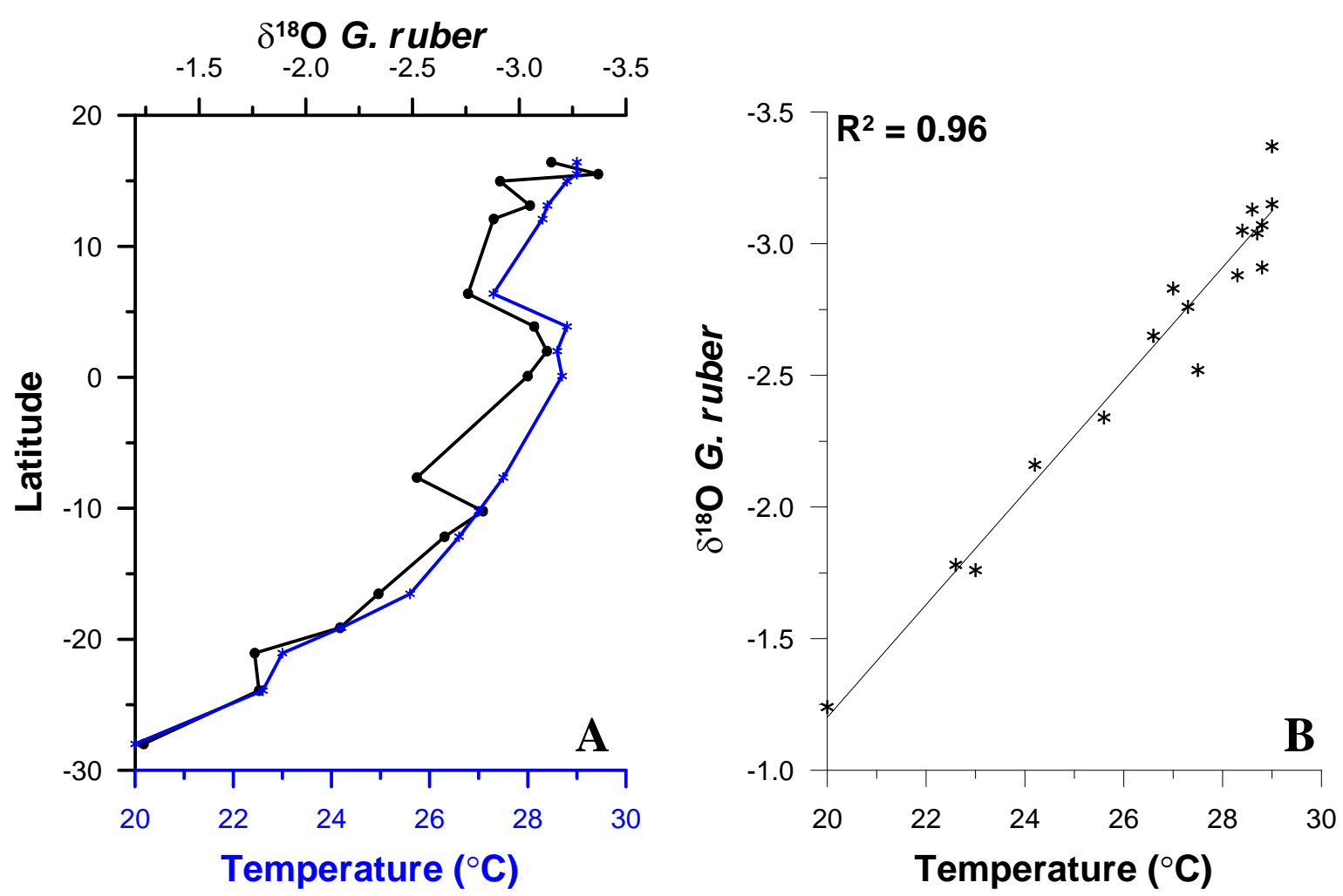

Figure: 3 